\title{
Glosa do wyroku Wojewódzkiego Sądu Administracyjnego w Szczecinie z dnia 29 maja 2014 r., I SA/Sz 32/14
}

Teza: Okoliczność, że skarżąca prowadzi czterogwiazdkowy hotel i wykorzystuje części budynku w postaci basenu, sauny, sali fitness oraz pomieszczenia z nimi związane (szatnia) również do prowadzenia działalności gospodarczej, nie ma znaczenia dla możliwości skorzystania przez nią z preferencyjnej stawki podatkowej z art. 5 ust. 1 pkt 2 lit. d) ustawy o podatkach i opłatach lokalnych, jeżeli są one równocześnie wykorzystywane przez nią do prowadzenia działalności leczniczej ${ }^{1}$.

\section{1.}

Glosowany wyrok jest dobrym przykładem konsekwencji, jakie powstają $\mathrm{w}$ obszarze stosowania elastycznego prawa podatkowego. Wyrok ten zasługuje na uwagę z dwóch względów - po pierwsze z uwagi na „ukazanie” zakresu regulacji przepisu określającego stawki podatku od nieruchomości, tzw. preferencyjne, po zmianach regulacji, jakie nastąpiły

\footnotetext{
1 „Monitor Podatkowy” 2014, nr 7, s. 43-45.
} 
z 1 lipca 2011 r. $^{2}$, po drugie zaś z uwagi na kolejny przykład dość partyzanckiego podejścia ustawodawcy podatkowego w zakresie wprowadzania regulacji elastycznego prawa podatkowego.

Pogląd przyjęty przez WSA w Szczecinie zasługuje w zasadzie na aprobatę, gdyż mieści się w zakresie elastyczności wywołanej brzmieniem regulacji przepisu art. 5 ust. 1 pkt 2 lit. d) ustawy o podatkach i opłatach lokalnych ${ }^{3}$, jednakże wymaga głębszych rozważań nad sposobem rozumienia spornej regulacji. Chodzi bowiem w szczególności o odpowiedź na pytanie, czy ustawodawca zamierzał wprowadzić taki stopień elastyczności tej regulacji, by objąć nią również przypadki, gdy - jak wskazał WSA w Szczecinie - „części budynku w postaci basenu, sauny, sali fitness oraz pomieszczenia z nimi związane (szatnia)” są wykorzystywane do działalności leczniczej i równocześnie do działalności gospodarczej. Może bowiem dojść do sytuacji, którą powinno „wychwycić” orzecznictwo sądów administracyjnych, że ustawodawca podatkowy poprzez nieumiejętne stosowanie wyrażeń tworzących elastyczne prawo podatkowe nie tylko wprowadzi regulacje zaburzające konstrukcję podatku od nieruchomości, lecz także jednocześnie wpłynie na relację pomiędzy obrotem gospodarczym a prawem podatkowym, tak istotną dla funkcjonowania również podatku od nieruchomości.

\section{2.}

Zmiany, jakie zostały dokonane przez ustawodawcę podatkowego w konstrukcji stawki podatkowej z art. 5 ust. 1 pkt 2 lit. d) ustawy o podatkach i opłatach lokalnych, w założeniu miały wyeliminować takie sytuacje, które utrwaliły się w ramach poprzednio obowiązującej regulacji tej stawki, gdy z jej preferencyjnej wysokości mogły korzystać wyłącznie te budynki lub ich części, w ramach których były realizowane świadczenia

2 Zmiany nastąpiły na mocy art. 133 ustawy z dnia 15 kwietnia 2011 r. o działalności leczniczej (Dz.U. Nr 112, poz. 654).

3 Ustawa z dnia 12 stycznia 1991 r. o podatkach i opłatach lokalnych (tekst jedn. Dz.U. z 2014 r., poz. 849, dalej: ustawa o podatkach i opłatach lokalnych). 
zdrowotne ${ }^{4}$. Istotnie niezrozumiała była sytuacja, gdy podmiot prowadzący działalność gospodarczą w zakresie udzielania świadczeń zdrowotnych mógł korzystać z tej preferencyjnej stawki wyłącznie w stosunku do pomieszczeń zajętych przykładowo na gabinety lekarskie czy rehabilitacyjne, jednakże nie mógł korzystać w stosunku do pomieszczeń, szatni, recepcji, socjalnych itp. Tym bardziej że trudno byłoby wyłączyć te „inne” pomieszczenia z elementu zorganizowanego sposobu prowadzenia działalności gospodarczej ${ }^{5}$.

Stąd też nie ulegało wątpliwości uzasadnienie do zmiany sformułowania kontrowersyjnej regulacji stawki podatku od nieruchomości. Wykorzystując to uzasadnienie, ustawodawca formułuje przepis art. 5 ust. 1 pkt 2 lit. d) ustawy o podatkach i opłatach lokalnych w dość charakterystyczny, a zarazem nowatorski - w stosunku do pozostałych regulacji art. 5 tej ustawy - sposób. Z jednej bowiem strony wprowadza szerokie określenie wskazujące na budynki lub ich części związane z udzielaniem świadczeń zdrowotnych w rozumieniu przepisów o działalności leczniczej, z drugiej zaś strony zawęża to określenie poprzez wyrażenie opierające się na „relacji zajęcia”, a zatem odnosi się do budynków lub ich części zajętych przez podmioty udzielające tych świadczeń. Wydaje się, iż otwarcie (uelastycznienie) zakresu tego zwrotu poprzez „relację związania” należy zasadniczo ocenić pozytywnie. Ustawodawca odszedł bowiem słusznie od funkcjonującego wcześniej określenia wskazującego na budynki lub ich

4 Zgodnie z przepisem art. 5 ust. 1 pkt 2 lit. d ustawy w brzmieniu obowiązującym do końca 2010 r. z preferencyjnej stawki podatku mogły korzystać budynki lub ich części zajęte na prowadzenie działalności gospodarczej w zakresie udzielania świadczeń zdrowotnych. W orzecznictwie wskazywano zatem na sposób stosowania tej stawki, odnosząc ją wyłącznie do budynku bądź części budynku, gdzie bezpośrednio są realizowane świadczenia zdrowotne. Przykładem może być wyrok Wojewódzkiego Sądu Administracyjnego w Bydgoszczy z dnia 10 stycznia 2012 r., I SA/Bd 761/11, w którym przyjęto, iż „1. Pojęcie «zajęcie na prowadzenie działalności gospodarczej w zakresie udzielania świadczeń zdrowotnych» należy wiązać z bezpośrednim związkiem pomieszczeń budynku z udzielaniem tego rodzaju świadczeń. Nie mieszczą się w jego ramach pomieszczenia o charakterze administracyjnym, gospodarczym i socjalnym, a także związane z zamieszkiwaniem oraz wyżywieniem kuracjuszy sanatorium (...)” (LEX nr 1107488).

5 Na temat zastosowania tego elementu pojęcia działalności gospodarczej w konstrukcji podatkowych dotyczących skutków działalności gospodarczej patrz: P. Borszowski, Działalność gospodarcza w konstrukcji prawnej podatku, Warszawa 2010. 
części związane z prowadzeniem działalności gospodarczej w zakresie udzielenia świadczeń zdrowotnych ${ }^{6}$. Tak sformułowany pierwszy człon (uelastyczniający) wprowadzał spore zamieszanie definicyjne z uwagi na trudności w ustaleniu relacji pomiędzy tym pojęciem a funkcjonującą już definicją gruntów, budynków i budowli związanych z prowadzeniem działalności gospodarczej ${ }^{7}$.

Obecna regulacja nie powoduje już zatem trudności w konieczności rozważenia stosowania definicji legalnej z art. 1a ust. 1 pkt 3 ustawy o podatkach i opłatach lokalnych, gdzie decydujące znaczenie ma kryterium „formalne” posiadania ${ }^{8}$. Powstaje zatem pytanie, w jaki sposób należy rozumieć ową relację związania, co powinien bardziej wyartykułować WSA w uzasadnieniu glosowanego rozstrzygnięcia. WSA w Szczecinie wskazał, iż „(..) możliwość zastosowania preferencyjnej stawki podatkowej na podstawie ww. przepisu nie wyłącza możliwości wykorzystywania powierzchni tych samych budynków lub ich części w innych celach, np. prywatnych, komercyjnych (...)”.

Wydaje się jednak, że warto podkreślić, iż relacja związania oznacza konieczność poszukiwania związku pomiędzy budynkiem czy częścią budynku a realizowaniem danego świadczenia zdrowotnego. Związek ten może wskazywać nie tylko na realizowanie danego świadczenia zdrowotnego w rozumieniu ustawy o działalności leczniczej w ramach konkretnego obiektu np. gabinetu, lecz także na wykorzystywaniu innych obiektów, które pozostają w pewnym związku z samym świadczeniem zdrowotnym, tym bardziej że pojęcie świadczenia zdrowotnego odnosi się do działań ${ }^{9}$. WSA w Szczecinie w głosowanym wyroku przywołał definicję świadcze-

6 Określenie to było pierwszym podejściem do rozszerzenia zakresu przepisu art. 5 ust. 1 pkt 2 lit. d) ustawy o podatkach i opłatach lokalnych.

7 Przepis art. 1a ust. 1 pkt 3 ustawy o podatkach i opłatach lokalnych.

8 Chociaż pojawiają się poglądy, które można określić jako wskazujące na kryterium materialne, bowiem odnoszące się do wykorzystania gruntów, budynków i budowli do prowadzenia działalności gospodarczej. Przykładem może być wyrok Naczelnego Sądu Administracyjnego w Warszawie z dnia 22 stycznia 2014 r., II FSK 130/12, CBOSA.

9 Zgodnie z art. 2 ust. 1 pkt 10 ustawy o działalności leczniczej świadczenie zdrowotne to działania służące zachowaniu, ratowaniu, przywracaniu lub poprawie zdrowia oraz inne działania medyczne wynikające z procesu leczenia lub przepisów odrębnych regulujących zasady ich wykonywania. 
nia zdrowotnego, jednakże należałoby poddać je pewnej analizie w odniesieniu do zwrotu, w którym wykorzystano określenie nieostre, a zatem zwrotu, gdzie użyto relację związania. Relacja ta powoduje konieczność podkreślenia istoty świadczenia zdrowotnego, tj. pewnych działań skierowanych na określone cele w przepisie art. 2 ust. 1 pkt 10 ustawy działalności leczniczej. Relacja związania budynków lub ich części powinna być zatem ustalana poprzez zakres konkretnych działań prowadzonych w określonym celu wynikającym z definicji świadczenia zdrowotnego, dla których realizacji są wykorzystywane budynki lub części takich budynków.

Nie ulega wątpliwości, iż zakres zwrotu odnoszącego się do budynków bądź ich części kwalifikowanych poprzez relację związania z działalnością określoną jako realizowanie świadczeń zdrowotnych jest zbyt szeroki, a zatem stopień elastyczności wywołany tym określeniem należało ograniczyć, tym bardziej że skutki tak określonej preferencyjnej stawki dotyczą bezpośrednio budżetu danej gminy. Stąd też ustawodawca słusznie ${ }^{10}$ posłużył się kolejną relacją, określaną mianem „relacji zajęcia”, by wyłączyć możliwość wyłącznie przedmiotowego traktowania preferencyjnej stawki, tj. takiego traktowania, gdy niezależnie od tego, jaki podmiot będzie realizował szeroko określone działania związane z udzielaniem świadczeń zdrowotnych, będzie mógł korzystać z tej preferencyjnej stawki. A zatem ustawodawca zamierzał ograniczyć możliwość korzystania z tej preferencyjnej stawki do takich podmiotów, które realizują świadczenia zdrowotne. Niestety, nie przewidział sytuacji, że tym samym otwiera możliwość jej zastosowania nie tylko do spornych niegdyś pomieszczeń recepcji, szatni, korytarzy itp., lecz także do basenu, sauny, sali fitness i innych, które równocześnie mogą być wykorzystywane do prowadzenia działalności gospodarczej. A zatem nie udało się zmniejszyć wykreowanego stopnia elastyczności.

10 W orzecznictwie jednoznacznie dostrzega się różnice w pojmowaniu tych dwóch wyrażeń ujmowanych umownie jako „relacja zajęcia” i „relacja związania”. Wypada zatem tytułem przykładu wskazać na wyrok Wojewódzkiego Sądu Administracyjnego w Warszawie z dnia 26 lutego 2013 r., III SA/Wa 3242/12, LEX nr 1453234, gdzie przyjęto, że „zajęcie gruntu na prowadzenie działalności gospodarczej (art. 1 ustawy z 1984 r. o podatku rolnym i art. 2 ust. 2 u.p.o.l.) jest ustawowym pojęciem o węższym zakresie od zakresu ustawowego pojęcia gruntu związanego z prowadzeniem działalności gospodarczej (art. 1a ust. 1 pkt 3 u.p.o.l.) (...)”. 


\section{3.}

Wprowadzenie zwrotu kreującego elastyczność w każdym przypadku, a zatem również w przypadku stawki podatkowej w podatku od nieruchomości, powinno przede wszystkim odpowiadać celowi, jaki ustawodawca podatkowy zakłada. Nie jest to zadanie łatwe, tym bardziej że w grę wchodzi realizacja wartości zewnętrznej systemu prawa z konsekwencjami dla konstrukcji prawnej podatku od nieruchomości, a zatem „fragmentu” prawa publicznego. Tym bardziej ustawodawca podatkowy powinien wykazywać „podniesiony standard legislacji”, aby nie doprowadzić do takich skutków, które niweczą wprowadzenie danej regulacji, tj. w tym przypadku stawki preferencyjnej. Nie ulega wątpliwości, iż wprowadzenie preferencyjnej stawki podatku od nieruchomości w analizowanym przypadku jest podyktowane określonym rodzajem działalności, tj. udzielaniem świadczeń zdrowotnych. A zatem cel wprowadzenia rozpatrywanej stawki podatku należałoby poszukiwać w odniesieniu do tej działalności, mając świadomość różnicy pojęć dotyczących celu i działalności. Inaczej mówiąc, ustawodawca zakłada określony cel wprowadzenia regulacji rozważanej stawki podatku, w obszarze którego koncentruje się działalność polegająca na udzielaniu świadczeń zdrowotnych. Zachowanie zatem właściwego stopnia elastyczności wymaga uwzględnienia relacji tej działalności do celu założonego przez ustawodawcę podatkowego. Oznacza to zatem brak możliwości postrzegania celu wprowadzenia przepisu art. 5 ust. 1 pkt 2 lit d ustawy o podatkach i opłatach lokalnych w oderwaniu od działalności polegającej na udzielaniu świadczeń zdrowotnych. Nie można zatem uzasadniać wykreowania zbyt dużego stopnia elastyczności różnicą w pojmowaniu celu w stosunku do działalności, w tym przypadku działalności polegającej na udzielaniu świadczeń zdrowotnych.

Obecnie obowiązująca regulacja jest przykładem wykreowania zbyt dużego stopnia elastyczności, który wykracza poza cel, który powinien zakładać ustawodawca podatkowy, powodując możliwość skorzystania ze stawki podatkowej również w przypadku tych podmiotów, które - jak słusznie przyjął WSA w glosowanym wyroku - prowadzą działalność w zakresie udzielania świadczeń zdrowotnych, ale równocześnie wyko- 
rzystują do prowadzenia działalności gospodarczej części budynku, w których „zlokalizowano” basen, saunę czy salę fitness. Powoduje to zatem nieuzasadnione stosowanie tej preferencyjnej stawki w stosunku do obiektów wskazanych powyżej, a wykorzystywanych do „typowej” działalności gospodarczej z negatywnymi konsekwencjami dla budżetów gmin.

Glosowany wyrok jest więc dobrym przykładem konieczności podjęcia działań nad weryfikacją sformułowania użytego przez ustawodawcę w rozpatrywanym przepisie art. 5 ust. 1 pkt 2 lit d ustawy o podatkach i opłatach lokalnych. Weryfikacja powinna pójść w kierunku zawężenia zakresu elastyczności wywołanej drugim członem sformowania, tj. tym, który w założeniu miał „dopinać” określoną szeroko regulację w pierwszej części tego przepisu. Należałoby zatem wskazać na budynki lub ich części „zajęte przez podmioty w zakresie udzielania świadczeń zdrowotnych".

\section{4.}

Wyrok WSA w Szczecinie z dnia 29 maja 2014 r. jest wyraźnym sygnałem, iż orzecznictwo podatkowe może i powinno być testerem elastycznego prawa podatkowego. Formułowanie bowiem określeń tworzących elastyczne prawo podatkowe w obecnych regulacjach często wskazuje na niedostrzeganie konsekwencji w postaci wykreowania zbyt dużego stopnia elastyczności z negatywnymi konsekwencjami dla budżetu bądź też z negatywnymi konsekwencjami dla podatnika. Prawidłowo „odczytywany” przez sąd administracyjny zakres wyrażenia, w którym wykorzystano określenie nieostre, powinien jednocześnie dać odpowiedź na pytanie, czy ustawodawca zrealizował założony cel regulacji.

To jednak dopiero początek właściwej drogi, gdyż w dalszej kolejności ustawodawca powinien korzystać z tego, w jaki sposób „wyraził” zakres elastyczności dany sąd administracyjny w swoim wyroku. Weryfikacja poprawności zarówno samego sposobu sformułowania określenia nieostrego, jak i jego umieszczenia w konstrukcji danej regulacji jest warunkiem powodzenia elastycznego prawa podatkowego i pewną gwarancją powstrzymania się przed nadmierną rozbudową regulacji podatkowych. 
Paweł Borszowski

\section{Bibliografia:}

Borszowski P., Działalność gospodarcza w konstrukcji prawnej podatku, Wolters Kluwer, Warszawa 2010. 